\title{
ENERGY SECURITY: CHALLENGES AND OPPORTUNITIES IN THE CASPIAN-BLACK SEA REGION
}

\author{
Roxana Andrei \\ Faculty of Economics - University of Coimbra, Portugal \\ Department of Balkan, Slavic and Oriental Studies - Macedonia University, Greece \\ roxanna.andrei@gmail.com
}

\begin{abstract}
The article will focus on the competition - cooperation continuum in the energy security framework of the Caspian - Black Sea region, arguing on the dual role of oil and natural gas resources and pipeline projects to fuel conflict and at the same time to build stability, in the context of the protracted conflicts in the region. It will debate on the conceptualisation of energy security in the traditional approaches of realism and neoliberalism, while proposing a social constructivist model of analysis that will go beyond the classical, state-centred theoretical streams. The role of the regional patterns of interactions, dynamics and actors in approaching energy security challenges and opportunities will be brought into light. The multiplicity and diversity of factors underpinning the energy security will be emphasised, bringing together insights on the political, economic, social and technological challenges and opportunities in the field on energy in the Caspian - Black Sea region.
\end{abstract}

Keywords: Caspian - Black Sea region; energy security; natural gas and oil; protracted conflicts; social constructivism 


\section{Security}

\section{Theorising Energy Security: beyond realist and neoliberalist approaches}

The section will attempt an incursion through both the mainstream, as well as through the critical efforts to theorise 'energy security', in the context of a rather scarce effort in the literature to provide more flexible and comprehensive understandings of the concept. The scholarship on energy security is relatively under-conceptualised (Stoddard, 2013) and there has been limited direct application of IR theories to understanding energy, energy-related conflicts and the patterns for competition and cooperation (Dannreuther, 2010). It mainly draws on the divergent interpretations between political realism and neoliberalism, transposed in the form of regarding energy security between geopolitics and market liberalism, both of them placing the inter-state political or economic structures at the core of their analysis (Ciută, 2010; Stoddard 2013).

The concept of energy security is rather a newcomer in the political, economic and academic debates, as it developed mainly after the oil crisis following the Arab-Israeli war in 1973, which led to the establishment of the International Energy Agency (IEA) one year later. In the 1990s, the logic of the energy relations was a predominantly economic one. In the last decades, however, the transition has been made to a political approach which gave rise to a new terminology of 'energy security', 'energy diplomacy', 'energy dependence', 'the geopolitics of energy' (Casier, 2011). The politicisation of the Russian natural gas exports to Europe and the shift from an economic interdependence to a political risk took place only recently, in the last decade, and occurred in the context of the EU's enlargement in 2004 and 2007 (Nies, 2011) and of the gas transit disputes with Ukraine (Terterov, 2010; see Sharples, 2013), in 2006, 2009 and 2014.

As such, energy security mainly focuses on the security of supply and on the affordable prices for the consumers, citizens and businesses, having "access to sufficient energy resources at reasonable prices for the foreseeable future free from serious risk of major disruption of service" (Barton et al., 2004: 5, see Winrow, 2007). Conceptualisation of energy security as a consumer-centric concept (Sharples, 2013), focused on the security of supply, has been feeding the theoretical fields of both political realism, concerned with the conflictual aspects of energy relations, as well as of neoliberalism/neoclassical economics, focused on the cooperative potential of energy relations at legal, economic and institutional level (Stoddard, 2013).

However, the exporter-states have their own energy security concerns, being preoccupied with securing stable markets, reliable transit partners able to pay the price 


\section{Security}

(Nies, 2011; Andrei, 2015) and maintaining the "security of demand" for their exports as a generator of revenues for the national economy (Yergin, 2006). Security of transportation routes, mainly of the natural gas terrestrial pipelines, which are vulnerable to numerous risks, is a middle element of security, both for supplier and consumer states. In their turn, transit states see energy security as a two-ended process, dependent both on producer and consumer states, in their struggle to be part of the major transportation projects (Andrei, 2015). Moreover, security of energy for developing countries is related to how changes in energy prices affect their balance of payments (Yergin, 2006).

\section{Traditional approaches on energy security}

The realist / geopolitical approach regards energy security as closely interlinked with violence and war, with states as main actors concerned about their survival translated into unperturbed access to resources and engaged in a zero-sum game. It argues, for example, that the scene of the future conflicts will be dominated by the struggle for resources, rather than by ideology or the global balance of power (Klare, 2008; see Stoddard, 2013). The focus is thus on international politics and energy security is defined mainly in the framework of the geopolitical competition of states over depleting resources, seen as a key ingredient of national power and national interest (Dannreuther, 2010), as a consequence of the combined effect of increasing global demand for energy and increasing concentration of energy supply in a few countries (Stoddard, 2013). Securitization occurs in the context of a threat perception by the consumer states and it contains a military component (Ciută, 2010; Langlois-Bertrand, 2010; Stoddard, 2013; Triantaphyllou, 2007). "Under this logic, energy security is derivative of geopolitics" (Langlois-Bertrand, 2010:11).

In practice, in the energy security debates over the Caspian - Black Sea region, the approach has been translated into the opposing interests of the West, represented by EU and US on one hand, and Russia on the other hand. EU and Russia are depicted as the protagonists of a zero-sum game, in which the gains of one party automatically imply the loss of the other and where by trying to get control over energy production and transmission, states seek to strengthen their relative position in the international system (Casier, 2011). In the realist-geopolitical perspective, oil and natural gas pipelines have strategic functions, engaging various state-level actors in using the transmission facilities 


\section{Security}

and infrastructure as political advantage. Pipelines projects are being developed in order to create and solidify strategic alliances and their defence entitles military actions.

According to this approach, the military campaigns in Chechnya were perceived as a strategic defence action by the Russian leadership who regarded the North Caucasus republic's claims of independence as a threat to Russian economic interests and strategic hegemony in the Caucasus and at the Caspian Sea. The realist view would further argue that this occurred in the context where the Chechen separatist leader, Dudaev, was in control on one of Russia's major pipelines, Baku-Novorosiisk, passing over 153 kilometres through the Chechen territory and was threatening, at the same time, Russia's gateway to the South Caucasus (Hughes, 2007).

The conflict in Chechnya should not however be reduced to a quest for securing strategic resources and transmission infrastructure, nor should it be limited to the action of the two state-level actors, Russia and Chechnya. The two campaigns have witnessed a high degree of variety of material and non-material factors acting as sources of conflict that were engaged by a diversity of inter-state, intra-state and individual actors. The war in Chechnya must be placed in the broader context of the political, institutional and ideological vacuum in the former Soviet space after the dissolution of USSR that privileged old and new elites to articulate national, religious and economic conflicting interests, on the background of an increased level of poverty and engagement in the shadow economy of both locals and of the Russian militaries, often cooperating and taking part together in military acts against competing, equally diverse, groups. The roots of the Chechen wars can be traced further back during the Soviet period and can be linked to deeper sociopsychological and behavioural aspects that fuel conflicts. In Chechnya, the well-paid jobs in the oil refineries were mainly reserved to the Russian urban workers during the Soviet Union, leaving many Chechens to deal with rural underpaid activities. With the gas and oil industry collapsing during the war, Chechnya became the scene of social unrest for many young people, angered with the unemployment and poverty they were facing, with the small elites who used their position and the political and military power for personal enrichment (Tishkov, 1997). None of the material or non-material factors can be solely held responsible for generating conflict. It is the mixture between realistic sources of conflict, such as material scarcity or access to limited positions and the subjective ones, as the expression of anger, anxiety and shame tied to personal or group level stress or the relative deprivation generating deeper resentments and a sense of inequality (Ho-Won Jeong, 2008). 


\section{Security}

Further critiques to the importance of the gas and oil resources in the conflicts of the Caucasus have been expressed. Although the competition for the oil resources did play a role on the agenda of the local elites often concealing their pragmatic goals under nationalist or religious discourses, securing the resources fails to explain Russia's military campaigns in Chechnya in contrast to the non-intervention and peaceful settlement with the oil-rich Tatarstan. Similarly, the control over resources does not qualify as a drive behind Georgia's war with Abkhazia, as the only strategic factor that could have worried Tbilisi was the loss of control over the railway linking Russia with Georgia, an import and export artery (Toft, 2003). At the same time, the neighbouring Ajaria did not experience war, although it was more important in terms of resources than Abkhazia, benefitting from the strategic location of the industrial port of Batumi, the Black Sea terminus of the oil pipeline Baku-Batumi (Toft, 2003).

The neoliberal or market-liberal approach downplays the role of power and focuses in return on the role of markets, institutions and companies, setting the energy security in the context of ensuring supply and price accessibility to foster win-win games. It argues that interdependence and not competition defines energy markets, thus the goal should be extending the markets and correcting its imperfections (Langlois-Bertrand, 2010; Stoddard, 2013).

Adepts of the neoliberal approach affirm that, despite efforts in the recent years towards diversification of the energy resources and transportation routes, the EU still finds itself in an asymmetric dependency relation to Russia, as a single natural gas supplier. This happens in the context of depletion of its own resources in the North Sea, enlargement of the EU and a growing gas demand and consumption. I argue that interdependence should nevertheless be treated with caution, as, despite absolute numbers, the implications are relative. Thus, diversification of the internal market and the fuel mix in the economy of the consumer states should also be taken into account. As an example, although it appears that Finland has a $100 \%$ dependency on the Russian gas, in reality, only $11 \%$ of its energy consumption is based on natural gas, nuclear power being the source preferred. Similarly, high dependence does not necessarily translate into a security threat, as it depends on the nature of relations between the supplier and the consumer country. The level of perceived threat and thus securitisation is lower, despite a higher energetic dependence, in the case of a beneficiary state in a friendly relation with the supplier state. The case of the GeorgianAzeri interdependence (Azerbaijan needs Georgia to transport its hydrocarbons, while Georgia needs Azerbaijan to supply them) has also led to a positive pattern of cooperation, 
with the Baku-Tbilisi-Ceyhan (BTC) and Baku-Tbilisi-Erzurum (BTE) pipelines offering a new role in the region for the two local actors, while also increasing their independence from Russia. Similarly, Kazakhstan, Turkmenistan and Uzbekistan have followed increasingly independent foreign policy orientations, challenging Russia's energy leverage over the region (Freire, 2012).

Dannreuther (2010) shifts away from the role of the markets and brings the conflict into the market-liberal perspective, placing within the economic neoliberal theory also the three literature strands on: 'resource curse' (dealing with the failure of the resource-rich states to develop other sectors of the economy and the factors which contribute to this, such as the 'Dutch disease'); on 'rentier state' (emphasising the consolidation of authoritarian, repressive regimes in resource-rich states and the impediments to the development of democratic states); and on 'resource wars' which he also connects to the political economy of 'new wars' literature (debating on the competition among various rival factions at intra-state level to predate natural resources, driven by greed rather than grievance). Cheterian (2008) argues, however, in a critical regard on the 'new wars', that the multinationals and the international financial institutions are not to be held responsible for the conflicts in the Caucasus, a region less exposed to the Western influence. The reasons are to be found rather in the collapse of the state structures and the security dilemma it created. The author argues that the economic and political global actors penetrated the region only at the late stage of the process. The "Deal of the Century", the oil deal between Azerbaijan and a consortium of Western companies, was signed as late as September 1994, after the cease-fire agreement in the Nagorno-Karabakh war, a conflict started during the Soviet rule.

\section{Energy security in a social constructivist view}

Attempts have been made in the literature to broaden the conceptualisation of energy, beyond the traditional approaches to include new factors of analysis. Ciută (2010:135) proposes a third dimension of energy security, beyond the ones of war or subsistence, a 'total' security where energy security means "the security of everything. resources, production plants, transportation networks, distribution outlets and even consumption patterns; everywhere: oilfields, pipelines, power plants, gas stations, homes; against everything. resource depletion, global warming, terrorism, them and ourselves". 


\section{Security}

Yergin brings in a more critical view taking into account the cultural and political aspects of energy security. Thus, the objective of energy security is "to assure adequate, reliable supplies of energy at reasonable prices and in ways that do not jeopardize major national values and objectives" (Yergin, 1988: 112; see Couder, 2015). Energy security thus encompasses a broader range of factors that come to interplay through the action of a variety of actors holding different interests and driven by various vulnerabilities. As such, energy security is also fuelled by the threat of terrorism, internal instability in some exporting countries, political turmoil, armed conflict, piracy and natural disasters that can affect the energy production and transmission.

Social constructivism looks into discourses as indicators of values and interests of political actors who define their interests through interaction with other actors (Sharples, 2013). Interests are no longer regarded through the traditional approaches as being objective and static (Snetkov, 2012), but they are being constantly redefined because of a 'process of mutual adjustment' (Wendt, 1999; see Sharples, 2013). The actors engage in security actions according to the subjective interpretations of their own interests whereas the conceptualisation and construction of their security needs and threats shape the discourse and security narratives employed for the larger goal of articulating their identity (Sharples, 2013; Snetkov, 2012; Eris, 2011). It can thus be argued that the actors in the Caspian - Black Sea region securitize energy according to their quest for assuming desired identities through the interaction with their neighbours, the larger regional actors, the global players and their own internal energy actors. Russia pursues the identity of a strong state, an indispensable supplier for the regional and the European market, while striving to acquire a more preeminent role on the Asian one as well. Turkey uses pipeline diplomacy in order to be recognised the role of a key regional player and energy hub, while also constructing its identity of an element of balance among various potential conflicting interests of the EU, Russia and Iran, by backing-up both Russian and Western-supported gas and oil pipeline projects. In their own turn, the regional actors along the transmission lines of oil and gas look for the construction and the recognition of their identities as important transit states.

Non-state actors, such as the state-owned and international companies - Gazprom, Socar, British Petroleum, and Lukoil have a strong voice in shaping the energy policies and strategies of the states. Azerbaijan signed the 'Deal of the Century' in 1994 with a consortium of international companies led by British Petroleum and Chevron, forming the Azerbaijan International Operating Consortium (AIOC) in order to develop three major oil 


\section{Securiaty}

fields at the Caspian Sea. This project clashed with the Caspian Pipeline Consortium (CPC), led by the Russian giant Lukoil, aspiring to have monopoly on transporting the oil from the Azeri oil fields at the Caspian Sea to Novorosiisk.

For constructivists, security is a "context-specific social construction" (Karakasis, 2015: 9) and it gains meaning through the inter-subjective processes between diverse actors for which threat is constructed in a discursive manner (Buzan and Waever, 1997). Various other interest groups and political factions engage in energy security narratives or use energy-driven interests to conduct political actions under ideological discourses. The ethno-national and religious discourse has been instrumentalised in the region in order to gain and secure access to energy resources and infrastructure. "It is the politicisation of the various clientelistic links between the political class and the new informal economy that provides the basis for mobilisation based on identity" (Kaldor, 2001: 55).

In 1999, the Russian oil company Transneft announced the construction of a bypass pipeline through that would avoid the Chechen territory where Russia had lost control over the Baku-Novorossisk pipeline during the first military campaign in Chechnya. In his discourse over the threat of the separatist forces emerging in Dagestan, Vladimir Putin warned that the Islamists in the republic threaten not only the Russia's territorial integrity but also its control of the economically vital oil export routes. On the other side, concerned with the loss of the main source of revenues should the Baku-Novorossisk pipeline have been diverted from Chechnya to Dagestan, in August 1999, the Chechen radical leader Shamil Basayev organised the invasion of Dagestan under the discourse of establishing an independent Islamic state in the neighbouring republic. If in the Russian case the public narrative was openly linking the security of the national state with energy, the discourse of the Chechen leaders concealed the pursuit of pragmatic goals under the religious flag.

\section{The competition-cooperation flux in the energy projects of the Caspian-Black Sea region}

Energy does not generate security on its own; it is rather located at the intersection of the political, economic, military, cultural and societal factors that shape the interactions among various actors and articulate their interests on the domestic and international scene. Changes in one or more of the fields of interaction impact on the way 


\section{Security}

energy is securitised or desecuritised. Thus, the oil and the gas pipelines projects in the Caspian-Black Sea region have a dual potential of both fuelling more tensions between the participants and of fostering cooperation in the area leading to its stabilisation. The role of the regional patterns of interactions, dynamics and actors is essential in approaching energy security challenges and opportunities in the wider Caspian-Black Sea region. Within the region, energy projects are closely connected to the frozen conflicts in the area, in Transnistria, Abkhazia, South Ossetia, Chechnya and Nagorno-Karabakh. More recently, the conflict in Eastern Ukraine has altered the narratives of all the energy actors in the region, with both EU and Russia pressing for developing competing alternative projects for the transport of natural gas that would bypass Ukraine. EU supported projects with a crossborder component, as part of its broader goal to advance EU strategic energy and trade interests. However, its investments in the Caspian region have been limited by the financial crisis and the competition with Russia (Simão, 2013). More than ever before, a political and military conflict was translated into an energetic threat for Europe and an economic interdependence was appropriated as a dependency risk and political leverage. Previously banned actors were allowed back as potential alternatives in EU's energy discourse, considering its diversification of supply from Turkmenistan and Iran. In its own turn, Russia used Gazprom to redefine its relations with Ukraine while also attempting a rapprochement with Turkey, a traditional partner in Western-backed projects transporting oil and gas from the Caspian to the Black Sea. Turkey itself sought the opportunity to expand its potential participation in both Russian and Western projects and to reassert its quest for a strong regional player identity.

The competition - cooperation continuum in the energy projects of the Caspian Black Sea region is shaped by the constant interaction between the state and non-state actors involved. Interaction, in its turn, shapes their perception on the self and on each other and leads to the construction of identities of friend or foe, strong or weak, key or secondary player etc. The oil and natural gas pipelines have, therefore, the potential of serving both as peace pipelines in a cooperative framework, as well as to deepen the animosities and tensions when engaged in a competitive pattern of interaction. Although the states cannot be dismissed as key players on the energy scene, the role of the nonstate actors is equally important in the process of conceptualising the energy security. The regional energy system is also characterised by a high degree of diversity in the domestic politico-economic structures whose interests are often divergent creating energy perceptions of risks between different energy actors (Stoddard, 2013). Other times, "similar 


\section{Securiagues}

actors (e.g. governments) can pursue different policies (e.g. energy independence or diversification of supply), and different actors can have similar policy preferences" (Ciută, 2010: 133).

The oscillating relations between Russia and Turkey relevantly illustrate the fluidity of the competition-cooperation patterns of interaction in the realm of energy security. The economic and political competition between Russia and Turkey in the Caucasus and in Central Asia in the first decades after the fall of the Soviet Union has witnessed a switch after the conflict in Ukraine in 2014, with new common projects being discussed. In December 2014, president Putin declared that the South Stream pipeline project would be abandoned, mainly due to Bulgaria's refusal to continue its participation in the project. Simultaneously, the launch of the Turkish Stream, carrying the Russian gas to Turkey and Greece has been announced, in an attempt to bypass Ukraine (Andrei, 2015). However, recent international and domestic events have questioned the future of the project in the light of the tensions between Moscow and Ankara. More important, the negotiations between Russia and Turkey reached a new level of tension and have frozen over Turkey's refusal to continue the project unless Gazprom agrees on a price cut, which, under Russia's domestic economic crisis, seems as an unlikely compromise. Moreover, the war in Syria impacts as well on the prospects of cooperation between the two countries, with Moscow hardly willing to compromise on Turkey's demands after the tensions between the two states escalated on the $24^{\text {th }}$ of November 2015 when a Russian jet fighter undergoing a mission on the Syrian border was shot down by the Turkish authorities.

Despite regional disagreements and tensions, the way forward could be integration, as a platform for developing sustainable inter-regional cooperation mechanisms spreading from energy to the other sectors as well (Freire, 2012) and thus contributing to the stabilisation of the region while also requiring a certain level of stability and reliability from the transit states. However, Turkey's attempts to assume a key role as a regional player did not succeed to "overcome the obstacles to community-building affecting regional relations, namely the permanence of the regional conflicts and closed borders, and in that sense has been insufficient to reverse the disintegration trend initiated with the end of the Soviet Union" (Simão, 2013:277).

In the context of the frozen conflict in Nagorno-Karabakh, the US-backed BakuTbilisi-Ceyhan oil pipeline was promoted by the liberal-pluralist approach as a 'peace pipeline', meant to reduce security tensions between Armenia and Azerbaijan, by benefiting all parties (Karagiannis, 2002; see Andrei, 2015). However, the realist approach emphasised 


\section{Security}

the zero-sum thinking of the two players. On one side, Azerbaijan feared that any route through Armenian-controlled territories would strengthen even more the Russian influence over the oil exports from Azerbaijan. On the other hand, Armenia enjoyed the status quo after the cease fire, being the de facto winner and in control over Nagorno-Karabakh, fearing, therefore, that increased revenues generated by the pipeline would shift the balance of power in favour of Azerbaijan (Karagiannis, 2002; see Andrei, 2015). In the last years, Azerbaijan used indeed its oil revenues to increase its military capacities and new tensions at the Armenian-Azerbaijani border emerged recently, with local military clashes between the two parties. Moreover, the oil and gas revenues allowed Azerbaijan to express a stronger voice in the region and to pressure for Armenia to be excluded from all the pipeline projects (Badalyan, 2011).

The BTC and BTE pipelines changed the status quo of power relations in the region, offering opportunities for Azerbaijan and Georgia to cooperate and to gain a plus of independence from Russia and to consolidate their role in the region (Li-Chen, 1999), thus to assume a new identity for themselves on the energy scene. Said (2007) argues that Russia perceived the BTC pipeline not only as an economic threat, but also as a geostrategic one, fearing that Chechnya, situated near the pipeline, would thus enter United States' sphere of influence in the region. The conflict in Chechnya posed questions on the security of the Baku-Novorossiysk pipeline, which passes through approximately $150 \mathrm{~km}$ of former conflict zones.

The pipeline crossing Chechnya could however serve also as an element of peace and stability, co-interesting both Russians and Chechens in maintaining a secure political and economic environment. In the more recent context of general economic slowdown, sanctions imposed by the EU and lack of funding, Russia will rather be interested in preserving the leverage on the internal gas market, while on its own part, Chechnya is interested in maintaining friendly supply and demand relations with Russia as it would be difficult to envisage who else would be willing to supply Chechnya under a liberalized market (Mitrova, 2015; see Andrei, 2015).

The factors for stabilisation the oil and gas pipelines can engage in the region are multi-levelled and go beyond the realm of the state actors and the political framework of analysis. Thus, the economic environment can benefit from an increased economic development of the states in the region, long-term contracts securing stable political relations, development of infrastructure and higher employment. Improvement of economic conditions can, in its turn, foster better standards of living, higher incomes, and increased 


\section{Security}

job security, cooperation that is more inter-ethnic and less incentive for separatism. Technology would be further encouraged to develop and renew, by building adjacent infrastructure (railways), introducing new technologies and looking into alternative energy resources.

\section{Conclusions}

Critical approaches of energy security can significantly contribute to broadening and understanding the concept through the interplay of a large spectrum of state and nonstate actors coming together in the competition-cooperation flux revolving around the natural gas and oil resources and pipeline projects in the Caspian-Black Sea region. The identity-interests-interpretation nexus can be used as a theoretical framework of understanding the processes of securitising energy and of defining patters of cooperation or competition in the area. The energy projects can serve both as prospects for fostering stability and cooperation as well as factors maintaining the status quo and contributing to the prolongation of the frozen conflicts of the region.

\section{References}

1. Andrei, R. (2015) 'Energy Security in South-East Europe: Natural Resources as Causes of Conflict or Building Stability" in: Balkan Social Science Review, 5, 63-87

2. Badalyan, L. (2011) "Interlinked Energy Supply and Security Challenges in the South Caucasus" in: Caucasus Analytical Digest, No.33, December 2011, 2-5

3. Buzan, B. and Waever, 0. (1997) Security: A New Framework for Analysis. Lynne Rienner Pub.

4. Casier, T. (2011) "Russia's Energy Leverage over the EU: Myth or Reality?" in: Perspectives on European Politics and Society, 12:4, 493-508

5. Cheterian, V. (2008) War and Peace in the Caucasus: Russia's Troubled Frontier. London: Hurst and Company

6. Ciută, F. (2010) "Conceptual Notes on Energy Security: Total or Banal Security?" in: Security Dialogue, 41(2): 123-144 


\section{Security}

7. Couder, J. (2015) "Energy Security, including Power Reliability. Literature review, with a focus on the impact of energy efficiency on energy security in the EU", Working Paper, University of Antwerp

8. Dannreuther, R. (2010) "International Relations Theories: Energy, Minerals and Conflict" in: POLINARES working paper n. 8, European Commission, $7^{\text {th }}$ Framework Programme

9. Eris, 0̈. Ü. (2011) "Energy Security and Turkey's Location in Europe's Neighbourhood" in: EU External Affairs Review, 24-36

10. Freire, M. R. (2012) "Russia's Energy Policies in Eurasia: Empowerment or Entrapment?" in Freire, M. R. and Kanet, R. E. (eds) Russia and its Near Neighbours. London: Palgrave Macmillan

11. Hughes, J. (2007). From Nationalism to Jihad. Philadelphia: University of Pennsylvania Press

12. Jeong, H-W. (2008) Understanding Conflict and Conflict Analysis. London: SAGE Publications Ltd

13. Kaldor, M. (2001) New and Old Wars. Stanford: Stanford University Press

14. Karagiannis, E. (2002) Energy and Security in the Caucasus. London: Routledge Curzon

15. Karakasis, V. P. (2015) "Energy Security and the Cyprus Question: "Securitization" of Energy in the Eastern Mediterranean" in: Politikon: IAPSS Political Science Journal, $27,5-31$

16. Langlois-Bertrand, S. (2010) "The Contemporary Concept of Energy Security", Defence R\&D Canada Centre for Operational Research and Analysis, Strategic Analysis Section, DRDC CORA CR 2010-148

17. Li - Chen, S. (1999) "In search of security: Azerbaijan and the role of oil in the Caspian Sea" in: Journal of Communist Studies and Transition Politics, 15:3, 24-53

18. Nies, S. (2011) "The EU-Russia Energy Relationship: European, Russian, Common Interests?" in Kanet, R. E. (ed) Russian Foreign Policy in the $21^{\text {st }}$ Century. London: Palgrave Macmillan

19. Sharples, J. D. (2013) "Russian approaches to energy security and climate change: Russian gas exports to the EU" in: Environmental Politics, 22:4

20. Simão, L. (2013) "Region-building in the eastern neighbourhood: assessing EU regional policies in the South Caucasus" in: East European Politics, 29:3, 273-288 


\section{Security}

21. Snetkov, A. (2012) "When the Internal and External Collide: A Social Constructivist Reading of Russia's Security Policy" in: Europe-Asia Studies, 64:3, 521-542

22. Stoddard, E. (2013) "Reconsidering the ontological foundations of international energy affairs: realist geopolitics, market liberalism and a politico-economic alternative" in: European Security, 22:4, 437-463

23. Tishkov, V. (1997) Ethnicity, Nationalism and Conflict in and after the Soviet Union: The Mind Aflame. London: Sage Publications

24. Toft, M. D. (2003). Identity, Interests, and the Indivisibility of Territory. Princeton: Princeton University Press

25. Triantaphyllou, D. (2007). "Energy Security and Common Foreign and Security Policy (CFSP): The Wider Black Sea Area Context" in: Southeast European and Black Sea Studies, 7:2, 289-302

26. Winrow, G. (2007) "Geopolitics and Energy Security in the Wider Black Sea Region" in: Southeast European and Black Sea Studies, 7:2, 217-235

27. Yergin, D. (2006) "Ensuring Energy Security" in: Foreign Affairs, 85:2, 69-82 


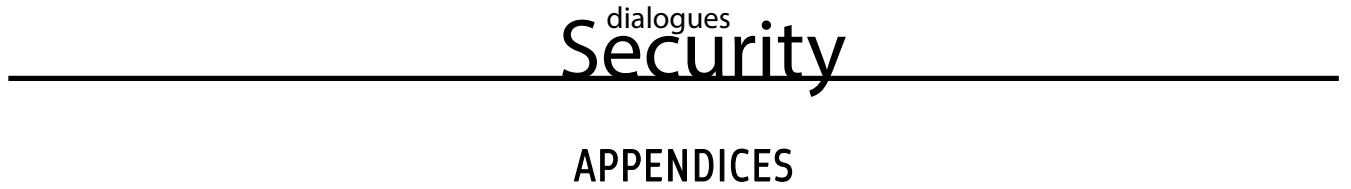

Appendix 1 - Fuel mix in the EU economies

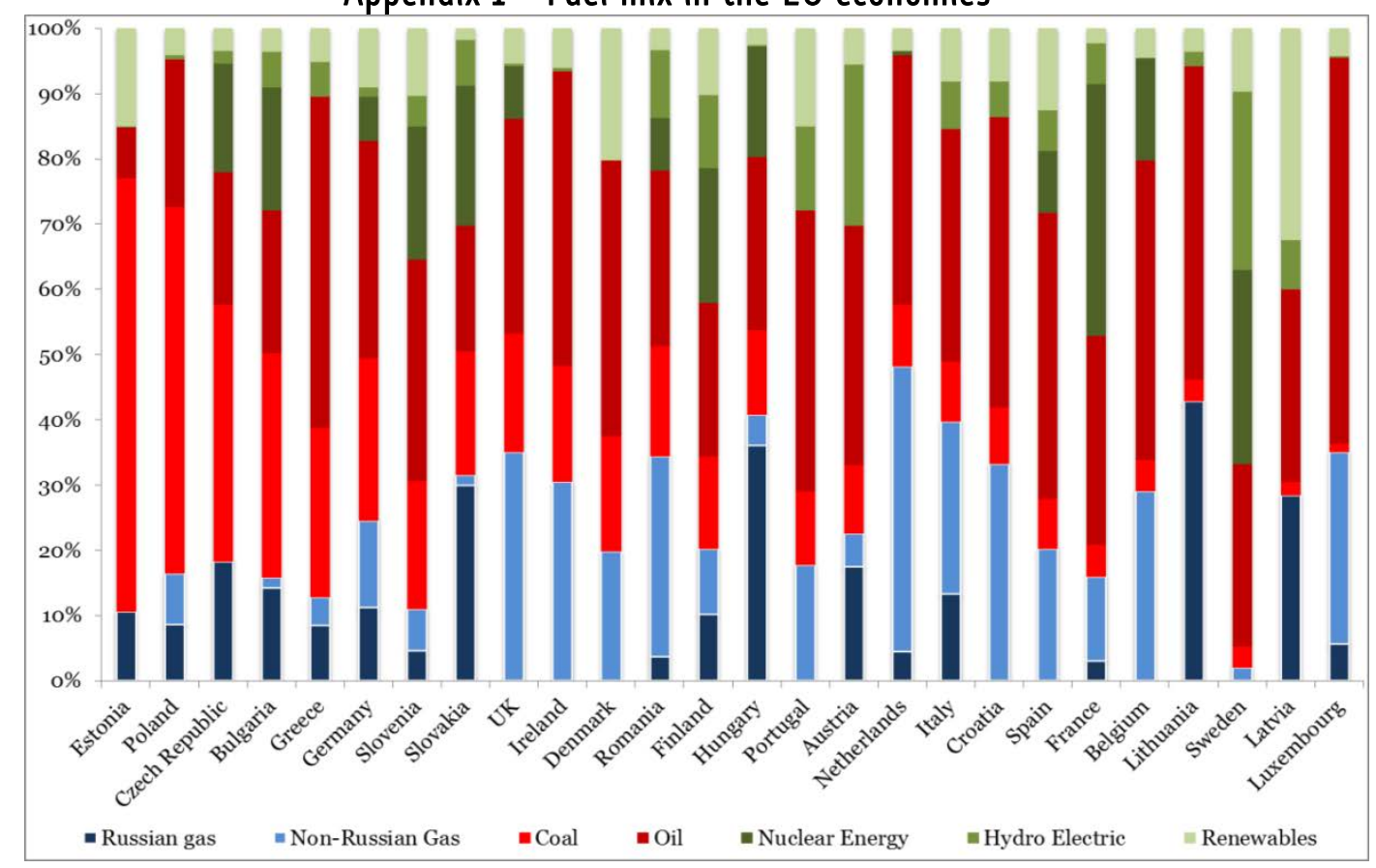

Source: IEA 2014 Gas Information, BP Statistical Review of World Energy 2014 


\section{Securiaty}

Appendix 2 - Natural gas and oil pipelines networks

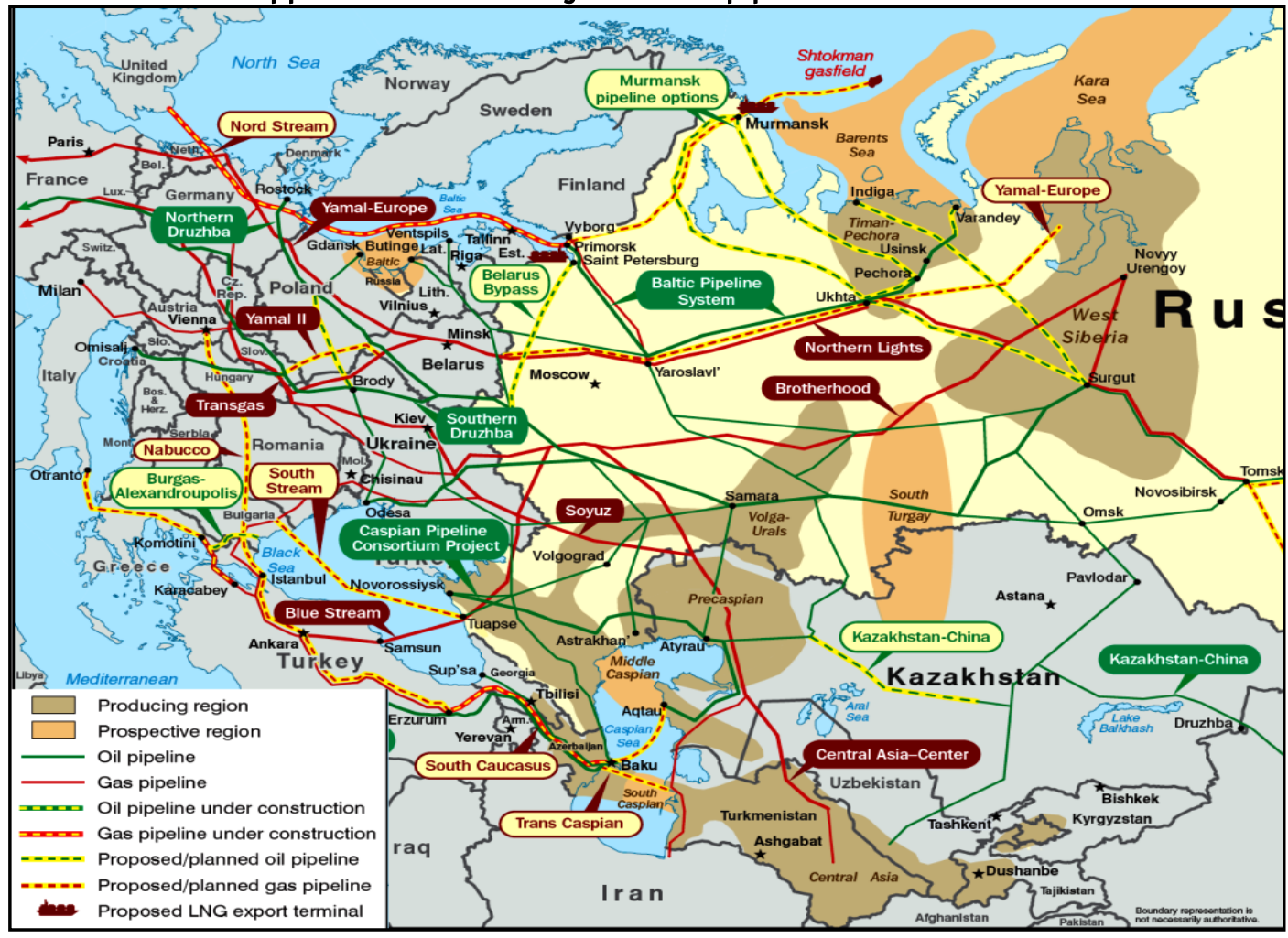

Source: www.aworldincrisis.org 


\section{Securialy}

Appendix 3 - Turkey / Russia: Energy Deals and Export Volumes

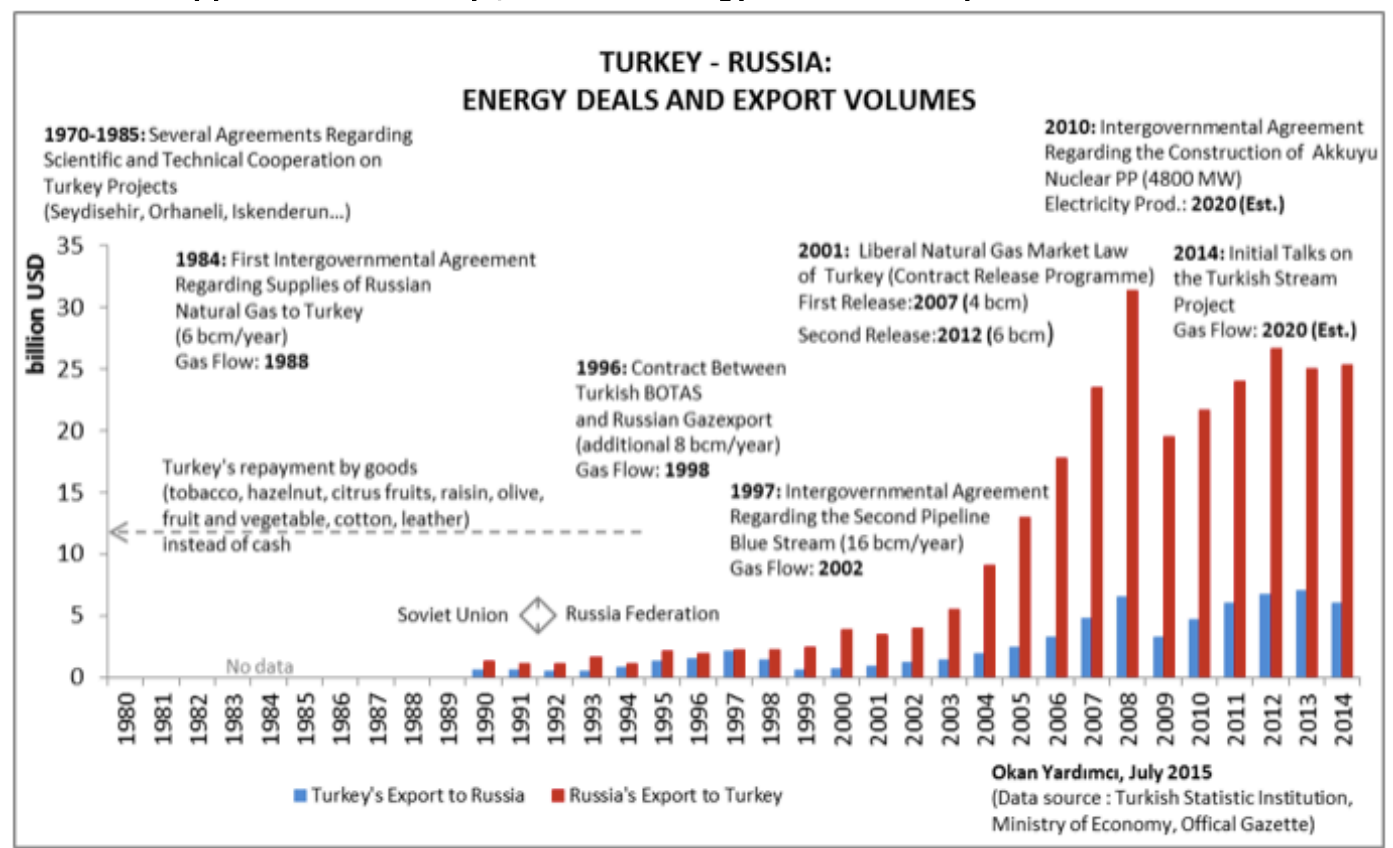

Source: http://www.naturalgaseurope.com/images/screen\%20shot\%202015-07-

16\%20at\%205_03_23\%20pm.png 